\title{
KUNDSKABSBASERET KRIMINALFORSORGSPOLITIK
}

\section{Af FORSKNINGSCHEF, DR. JUR. BRITTA KYVSGAARD}

This article discusses evidence-based correctional programmes and the extent to which they have produced positive preventive effects. It also provides a general overview of the rationales for using evidence-based programmes within the Nordic correctional system. The article concludes with discussions of the need for alternative educational methods within prisons, the tendency towards exaggerated optimism concerning treatment effects, and the limitations of programmes initiated within correctional settings."

Titlen på dette seminarium er kundskabsbaseret kriminalforsorgspolitik. Dette emne, mener jeg, skal afgrænses således, at diskussionen skal angå den indsats, som kriminalforsorgen gør eller kunne gøre, og som er baseret på tilgængelig forskningsbaseret kundskab om en præventiv effekt. Det drejer sig altså alene om de former for tiltag, der igangsættes efter, spørgsmålet om straf er afgjort, og ikke om betydningen af straffen. Spørgsmålet om effekten af straf henhører efter min vurdering under den kundskabsbaserede kriminalpolitik.

I det følgende skal jeg kort først diskutere, hvad vi ved om effekterne af forskellige tiltag inden for kriminalforsorgen. Jeg vil efterfølgende omtale nogle spørgsmål, som relaterer sig til den kundskabs- eller evidensbaserede tilgang. Mit oplæg om effekterne af forskellige tiltag inden for kriminalforsorgen er baseret på en artikel, jeg har skrevet, og som er et resultat af en temadag, som den danske kriminalistforening afholdt i november 2005 om "Hvad virker - hvad virker ikke?" (Kyvsgaard 2006). Jeg skal tillade mig at henvise til denne artikel, hvor spørgsmålene drøftes mere fyldestgørende, end det vil være muligt her.

\section{Kundskabsbaserede programmer i den nordiske kriminalforsorg}

Lad mig indledningsvis slå fast, at det kundskabsbaserede perspektivet har fået rodfæste inden for kriminalforsorgen i Norden. Hvis man ser på de nordiske kriminalforsorgsmyndigheders hjemmesider, vil man finde, at alle anvender programmer, som er blevet evaluerede, og som kan kaldes evidensbaserede.

De fleste anvender almene kognitive programmer, og alle anvender særlige programmer for seksualforbrydere, for voldsforbrydere og for kriminelle med misbrugsproblemer. Jeg skal senere vende lidt tilbage til, hvilken type program det drejer sig om i de forskellige lande.

\footnotetext{
* Title in English: Evidence-Based Correctional Policy. Original in Danish.
} 
Det forekommer derimod noget mere sjældent, at der gennemføres gode videnskabelige effektevalueringer i de nordiske lande. Det betyder, at vi typisk baserer os på amerikansk, på engelsk eller på canadisk forskning, når vi skal finde ud af, hvad der er effektivt, og hvad der ikke er det. Over for denne forsamling er det næppe nødvendigt at argumentere for, at det selvfølgelig ville være betydeligt bedre, hvis vi kunne basere vor kundskab på nordisk forskning. Der er et klart behov for, at der satses mere på dette område.

\section{Hvorfor en kundskabsbaseret tilgang?}

Der er én væsentlig grund til at understøtte og satse på forskning i effekten af de forskellige tiltag, og - ikke mindst - at anvende denne forskning i praksis. Det er, at noget kan gå forskrækkeligt galt, hvis vi ikke gør det.

Når vi planlægger nye tiltag, har det hidtil typisk været baseret på common sense og på vore egne antagelser om, hvad der virker - om hvad der er godt, og hvad der er skidt. Men det, vi kan opfatte som åbenbart 'effektive' og 'gode' tiltag, kan virke meget anderledes på dem, som tiltaget rettes mod. Det er mennesker, som ofte lever et ganske anderledes liv, og som kan se verden på en anden måde end den, vi udgår fra, når vi planlægger. Det, som kan forekomme åbenbart afskrækkende på de fleste af os, kan på andre virke tillokkende.

Det mest velkendte eksempel på et ineffektivt $\mathrm{og}$ - viser de fleste evalueringer - direkte skadeligt program er Scared Straight (se bl.a. Finckenauer 1982; Kyvsgaard 1990; Petrosino, Turpin-Petrosino \& Buehler 2005). Der findes imidlertid mange flere eksempler på programmer, der risikerer at fremme frem for at hæmme kriminel adfærd. Typisk er det tiltag, der sigter på at afskrække lovovertræderen, som risikerer at medføre en negativ effekt. Eksempelvis har de forsøg med kortvarige fængslinger af unge lovovertrædere, som er gennemført i USA, vist, at denne form for 'chok-behandling' risikerer at fremme kriminalitet (MacKenzie 2002). Særligt hårde eller afskrækkende afsoningsvilkår har heller ikke en positiv præventiv effekt. Fra USA kender vi til ydmygende behandling af fanger - om Chain Gangs og om iklædning af fanger i stribet fangedragt. Der findes intet som helst bevis for, at det afskrækker (Gendreau et al. 2002). Og en ny undersøgelse viser, at maximum security fængsler ikke medfører mindre recidiv end minimum security fængsler (Chen \& Shapiro 2007).

\section{Kognitive programmer}

Det, der var begyndelsen på den kundskabs- eller evidensbaserede kriminalforsorgspolitik i de nordiske lande - i det mindste i Danmark - var importen af forskellige kognitive programmer fra Canada. Den type program anvendes i alle nordiske lande i dag. 
De evalueringer, der er gennemført, tyder på, at de almene kognitive færdighedsprogrammer, som anvendes over for stort set alle grupper af lovovertrædere, giver en positiv kriminalpræventiv effekt. Den præcise effektstørrelse er svær at angive, da forskellige metaanalyser når til forskellige resultater: fra 8 til 27 procent reduktion i recidivrisikoen (Kyvsgaard 2006; Tong \& Farrington 2007).

Programmer for voldsdømte og andre med vanskeligheder med at håndtere aggressioner anvendes i alle nordiske lande. Anger Management anvendes i Danmark og Island, Aggression Replacement Treatment (ART) anvendes i Sverige, og blandt andet noget, som hedder Cognitive Self Change, anvendes i Finland. I Norge anvender man primært programmet Alternativ-til-vold (ATV). Dette program er ikke, som de ovennævnte programmer, baseret på kognitiv teori.

Internationalt er der først og fremmest gennemført evalueringer af det program, som anvendes i Sverige, Aggression Replacement Treatment. Og evalueringerne viser generelt set ganske positive effekter, nemlig en reduktion i recidivet på omkring 15-20 procent (Kyvsgaard 2006).

Derimod er der ikke påvist sikre positive effekter af det program, som anvendes i Danmark og i Island, Anger Management. I Danmark diskuterer man da også for tiden, om det er et godt program. Et problem ved programmet kan være, at det er alt for kortvarigt til, at man kan forvente en stabil og permanent effekt. Det Anger Management program, man anvender over for unge i Danmark, inkluderer således kun otte lektioner. I modsætning hertil varer ART-programmet 10 uger med tre møder ugentligt, og hvert møde varer tre timer.

\section{Særlige grupper af lovovertrædere}

For så vidt angår særlige grupper af lovovertrædere, så viser den internationale forskning, at programmer for seksualforbrydere især har givet positive resultater, når behandlingen er foregået i frihed. I en nyere metaanalyse peges på en 37 procents reduktion i recidivrisikoen efter anvendelse af især kognitive programmer (Lösel \& Schmucker 2005). Det er her den almene recidivrisiko, som er i fokus. Det er således overordentligt svært at påvise en effekt vedrørende alene seksualforbrydelser, eftersom recidiv til nye seksualforbrydelser forekommer ganske sjældent.

Med hensyn til behandling af seksualforbrydere i fængsel er resultaterne mere usikre. Der er dog en tendens i positiv retning.

I denne forbindelse skal nævnes, at en dansk undersøgelse af betydningen af kemisk kastration peger på positive resultater. Her er resultatet målt ved recidiv til nye seksualforbrydelser (Mollerup, Gabrielsen \& Jessen-Petersen 2006). Det skal dog fremhæves, at det dels drejer sig om en stærkt selekteret gruppe, som modtager denne behandling, og at resultatet er lidt usikkert på grund af en ikkesammenlignelig kontrolgruppe. Det fremgår endvidere af en svensk rapport, at 
medicinsk kastration ikke kan stå alene. I rapporten, der er fra den svenske Kriminalvård, skriver psykolog Elisabeth Kwarnmark, at forskning viser, at "enbart kemisk kastration inte fungerar" (www.kvv.se).

I øvrigt ser det ud til, at man anvender forskellige programmer til seksualforbrydere i de nordiske lande: I Finland anvender man et program, der hedder STOP, i Sverige ROS (Relations- och samlevdandsprogram), mens man i Norge også anvender ATV i forhold til seksualiseret vold. I Island anvendes et kognitivt program.

Vedrørende lovovertrædere med misbrugsproblemer er det først og fremmest effekten af terapeutiske samfund, der er undersøgt. Den terapeutiske samfundsmodel synes at give positive resultater, især når behandlingen fortsætter efter løsladelsen (Kyvsgaard 2006). Modellen anvendes over for kriminelle misbrugere i både Sverige, Finland og Danmark. I Sverige er der gennemført en evaluering, som påviser positive resultater af behandlingen (Fridell \& Hesse 2005). Den finske misbrugsbehandling af indsatte inkluderer også kognitive programmer, og behandling fortsætter efter løsladelsen.

I Norge anvendes andre programmer, dels et der hedder RIF - rusprogram i fengelse $-o g$ dels et der hedder Mit-Valg. Begge programmer er baseret på kognitiv teori, men inkluderer også andre elementer. Også i Island behandler man narkomaner i fængsler, men jeg ved ikke præcis, hvilken type program det drejer sig om.

Der er imidlertid også nogle former for tiltag over for misbrugere, der ikke medfører positive resultater. Det er den type, der alene omfatter urinprøvekontrol. De udenlandske undersøgelser, der er gennemført vedrørende den præventive effekt af dette tiltag, har ikke kunnet påvise positive effekter (MacKenzie 2002). Det skal tilføjes, at det i en dansk undersøgelse af betydningen af urinprøvekontrol er påpeget, at urinprøvekontrollen kan have en positiv effekt på fængselsmiljøet (Kriminalforsorgen 2006).

\section{Arbejde og uddannelse}

Lad mig ganske kort nævne resultaterne af den forskning, der er gennemført vedrørende effekten af arbejde eller uddannelse under strafafsoningen.

I den internationale forskning har man påvist, små, men positive effekter af arbejdstræning. Der synes især at være en sandsynlighed for et positivt resultat, såfremt arbejdstræningen er forbundet med uddannelse. Man finder ligeledes små, men positive effekter af erhvervsuddannelsen inden for kriminalforsorgen, ligesom tilfældet er for frigang til uddannelse og af støtte til at finde et arbejde efter løsladelsen.

Med hensyn til den almene skoleuddannelse er resultaterne svagere. Der er således mange undersøgelser, som ikke har kunnet påvise en klar effekt, men enkelte har dog. 
I forlængelse heraf kan der nævnes en svensk undersøgelse af betydningen af at deltage i uddannelse under afsoningen (Herkner \& Samuelsson 2005). Undersøgelsen viser, at de, der har valgt at studere, får forbedret deres læse- og skrivefærdigheder. Desværre inkluderer undersøgelsen dog ikke oplysninger om, hvorvidt dette har betydning for recidivrisikoen.

Det gør derimod en ældre, dansk undersøgelse, der ser på effekten af den såkaldte Skadhaugeplan (Holstein 1986). Denne undersøgelse viser, at der ikke var forskel på recidivprocenten for dem, som havde modtaget og gennemført en uddannelse i fængsel, i forhold til dem, som havde påbegyndt, men ikke fuldført uddannelsen, og dem, som slet ikke var kommet i gang med en uddannelse under afsoningen. Recidivprocenten var altså den samme i alle tre grupper. Undersøgelsen kunne derimod vise en positiv effekt af at have haft frigang til uddannelse. Der var altså en lavere recidivprocent for dem, som tog en uddannelse på de almindelige uddannelsesinstitutioner uden for fængslet. Forfatteren til undersøgelsen mener, at dette kan bero på, at uddannelse sammen med 'almindelige' elever i højere grad end uddannelse i fængsel kan medføre, at den indsatte vender ryggen til kriminalitet og fængselstilværelsen.

Denne tolkning støttes af en nyere dansk undersøgelse, som viser, at lovovertrædere påvirkes positivt af omgang med 'almindelige mennesker' - eller omvendt: Hvis de undgår den negative påvirkning, som foregår i fængsler, er der mindre risiko for recidiv (Minke 2006).

\section{Behov for en plan B?}

Effektforskningen rejser visse spørgsmål. Det første, jeg gerne vil tage op, angår uddannelsen i fængslerne.

Spørgsmålet relaterer sig til en oplevelse, jeg havde for nylig, hvor jeg var blevet bedt om at give et oplæg på et møde i den danske fængselslærerforening. Oplægget handlede netop om effekten af uddannelse i kriminalforsorgen. Som sagt er de påviste effekter på dette område små og lidt usikre.

Under den efterfølgende diskussion blev det klart, at der ikke anvendes særlige uddannelsesmetoder inden for kriminalforsorgen. Det ser i hvert fald ikke ud til at være tilfældet i den danske kriminalforsorg. Men er der ét sted, der er behov for en plan B - for alternative uddannelsesmetoder - så er det vel netop i kriminalforsorgen. Her har vi at gøre med en gruppe mennesker, som i vældig mange tilfælde har haft problemer med og har oplevet modgang i den almindelige skole. Hvis man bare fortsætter med at anvende samme metode, som fangerne kender fra folkeskolen, og som de har haft vanskeligheder med, så er det vel ikke så underligt, at det er så svært at registrere væsentlige præventive effekter af uddannelse under strafafsoning. 
Samtidig viser en ny dansk undersøgelse, at kun 20 procent af fangerne i de danske fængsler deltager $i$ undervisning under afsoningen, og at mange flere, nemlig 33 procent, kunne tænke sig at tage en erhvervsuddannelse under afsoningen (Koudahl 2007).

Jeg tror, og jeg skal stærkt understrege, at det alene er en tro, men jeg tror, at man med en større satsning på uddannelse under strafafsoningen måske vil kunne opnå meget bedre resultater, end man gør ved de mange og populære kognitive programmer.

\section{Overoptimisme på behandlingsfronten?}

I en artikel i Fængselsfunktionæren er den tidligere direktør for den canadiske kriminalforsorg citeret for at sige, at man bør overveje at undlade at prøveløslade de fanger, som ikke vil deltage i programvirksomheden i fængslerne (Væver 2004).

Efter min vurdering er det at gå for vidt. De effekter, vi kan måle af forskellige programmer, er så små, at jeg ikke mener, at det på nogen måde kan legitimere, at fanger holdes længere tid i fængsel, hvis de ikke vil deltage i behandlingsprogrammer.

Som mange sikkert husker, så har kriminalforsorgen tidligere i historien været domineret af en behandlingsideologi. I den tidligere periode havde vi en række tidsubestemte sanktioner, hvor idéen groft sagt var, at fangerne først skulle løslades, når de blev anset for at være kureret for deres kriminelle tilbøjeligheder. Dengang - i 1970erne - blev behandlingsideologien kritiseret for, at det var personernes behandlingsbehov, som skulle bestemme, hvor lang tid, de skulle opholde sig i fængslet.

I dag synes situationen at være en lidt anden. I dag synes det at være fangernes deltagelse i behandling og programvirksomhed, som kan få betydning for, hvor længe de skal opholde sig i fængsel. I Danmark har man således indført et princip, som hedder 'Noget for Noget'. Det indebærer, at de fanger, som deltager i programvirksomhed og på anden måde forsøger at forbedre sig, har mulighed for prøveløsladelse allerede efter halv tid.

\section{Urealistiske behandlingsprincipper?}

Er tredje spørgsmål, som jeg gerne vil rejse, er, om det overhovedet er muligt i fængslerne at gennemføre behandling eller programmer, som vi ved, det bør gøres.

Vi ved således, at det ikke bare er et spørgsmål om at anvende et evidensbaseret program for at opnå præventive effekter. En vældig lang række af omstændigheder skal være opfyldt, for at programmet kan få en effekt. Hvis man anvender et velafprøvet program fejlagtigt eller over for den forkerte målgruppe, vil man ikke opnå en positiv effekt.

I den international forskning er der opstillet 18 behandlingsprincipper, som man skal tage i betragtning, når et program implementeres (Andrews 2001; An- 
dreassen 2003). På papiret er alle disse principper vældigt gode og korrekte, men jeg vil stille spørgsmålstegn ved, om det i det hele taget er muligt at leve op til alle disse principper.

Der er ikke her tid at gennemgå alle disse principper, men jeg skal bare nævne nogle få, herunder dem, som man antagelig i særlig grad vil have svært ved at leve op til i fængslerne.

- Behandlingen skal tilpasses den enkeltes indlæringsevne. Det betyder, at man ikke kan anvende samme fremgangmåde over for alle.

- Man skal ikke kun satse på en programtype, men der bør være en mangfoldighed af tiltag og behandlingsprogrammer, eftersom de indsatte har forskellige problemer og forskellige behov, som skal adresseres. Før igangsættelse af behandling skal den enkeltes behov derfor også først kortlægges.

- Man skal forsøge at inddrage den indsattes sociale miljø uden for fængslet i behandlingen.

- Personalet på institutionerne skal være enige om institutionens principper, om behandlingen og om, hvordan bl.a. konflikter håndteres.

- Man skal forsøge at modvirke den negative påvirkning, der sker mellem indsatte $\mathrm{i}$ institutioner.

- Institutionsopholdet må ikke vare længere end højst nødvendigt vurderet ud fra en behandlingsmæssig synsvinkel.

Over for alle disse idealer og principper står så den virkelighed, som bl.a. en tidligere fængselsbetjent har berettet om i bogen "16 år i fængsel. En fængselsbetjents beretning om at arbejde blandt mordere, psykopater og narkomaner" (Lund 2003). Det, der er interessant i denne bog, er, at begreber som behandling, programvirksomhed, uddannelse og resocialisering ikke forekommer i bogen. Dette synes ikke at være en del af fængselslivet. Bogen gennemsyres derimod af én bestemt underliggende beretning, nemlig beretningen om, at arbejdet for en fængselsfunktionær først og fremmest går ud på at undgå konflikter. Indirekte, men dog vældigt tydeligt, fremgår det af bogen, at en god dag er en dag, hvor der ikke har været konflikter med fangerne - en god dag er en stille og rolig dag, hvor alle bare passer sit, og fangerne afsoner uden videre vrøvl.

Denne beretning om fængselstilværelsen er helt i overensstemmelse med resultaterne fra nyere engelsk fængselsforskning. I denne forskning understreges det således, at fængselsfunktionærens vigtigste kompetence er at være fredsbevarende (Liebling, Price \& Elliott (1999).

Er det overhovedet muligt at gennemføre de mange idealer, de mange principper og de forskellige programmer inden for rammerne af en sådan konfliktkultur? 
Vores erfaring siger, at vi må svare ja på et sådant spørgsmål, men den siger også, at selve strukturen, kravet om sikkerhed og de mange latente konflikter i fængslet medfører, at det er meget svært, og at mulighederne er ganske begrænsede.

Det får mig til at konkludere, at det i dag utvivlsomt i mindre grad er mangel på kundskab om effektive metoder, end det er mangel på vilje og mulighed, som sætter grænse for det kriminalpræventive arbejde inden for kriminalforsorgen.

\section{Litteratur}

Andreassen, T. (2003). Institutionsbehandling av ungdomar. Gothia, Stockholm.

Andrews, D.A.. (2001): Principles of Effective Correctional Programs. I: Motiuk \& Serin (ed.): Compendium 2000 on Effective Correctional programming. Correctional Service Canada,

Chen M.K. \& J.M. Shapiro (2007): Do Harsher Prison Conditions Reduce Recidivism? A Discontinuity-Based Approach. American Law and Economics Review, vol. 9, s. 1-29.

Finckenauer, J.O. (1982): Scared straight and the panacea phenomenon. PrenticeHall, New Jersey.

Fridell, M. \& Hesse, M. (2005): Psykosociala interventionsmetoder vid kriminalitet och drogmissbruk. www.bra.se.

Gendreau, P. et al. (2002): The Common-Sense Revolution and Correctional Policy. In: McGuire, J. (ed.): Offender Rehabilitation and Treatment. John Wiley and Sons, Chicester, p. 259-388.

Herkner, B. \& S. Samuelsson (2005): Utbildning inom kriminalvården. Effekter på de intagnas läs- och skrivfärdigheter. Forskningskommittén rapport nr 15.

Holstein, B. (1986): Uddannelse og recidiv. Justitsministeriet, Kriminalpolitisk forskningsgruppe, forskningsrapport nr. 28.

Koudahl, P. (2007): Indsatte $i$ danske fcengsler. Uddannelse og uddannelsesønsker. www. kriminalforsorgen.dk.

Kriminalforsorgen (2006): Evaluering af den skarpede urinprøvekontrol. www. kriminalforsorgen.dk.

Kyvsgaard, B. (1990): Skræmt til lovlydighed? Danske forsøg med aversions-terapi. I: Kyvsgaard, B., A. Snare \& P. Wilhjelm (red.): Forebyggelsens veje og vildveje. Kriminalistisk Instituts Stencilserie, 58.

Kyvsgaard, B.(2006): Virksomme og uvirksomme programmer og behandlingstiltag. B. Kyvsgaard (red.): Hvad virker - hvad virker ikke? Kundskabsbaseret kriminalpolitik og praksis. København: Jurist- og økonomforbundets forlag, s. 83-108.

Liebling, A., D. Price \& C. Elliott (1999): Appriciative inquiry and relationships in prison. Punishment and Society, vol. 1, s. 71-98. 
Lund, P. (2003): 16 år I fængsel. En fængselsbetjents beretning om at arbejde blandt mordere, psykopater og narkomaner. København: Lademann.

Lösel, F. \& M. Schmucker (2005): The Effectiveness of Treatment for Sexual Offenders: A Comprehensive Meta-Analysis. Journal of Experimental Criminology, vol. 1, p. 117-146.

MacKenzie, D.L. (2002): Reducing the Criminal Activities of Known Offenders and Delinquents: Crime Prevention in the Courts and Corrections. In: Sherman, L. et al. (ed.): Evidence-Based Crime Prevention. Routledge, London and New York.

Minke, L.K.(2006): Om at blande kriminelt belastede med ikke kriminelt belastede. B. Kyvsgaard (red.): Hvad virker - hvad virker ikke? Kundskabsbaseret kriminalpolitik og praksis. København: Jurist- og økonomforbundets forlag, s. 83-108.

Mollerup, S., G. Gabrielsen \& B. Jessen-Petersen (2006): Behandling af scedelighedskriminelle i Anstalten ved Herstedvester. www. kriminalforsorgen.dk.

Petrosino, A., C. Turpin-Petrosino, \& J. Buehler (2005): Scared Straight' and other Juvenile Awareness Programs for Preventing Juvenile Delinquency. www. campbellcooperation.org.

Tong, L.S.J. \& D.P. Farrington (2007): Effectiveness of "Reasoning and Rehablitation" in Reducing Reoffending. In press.

Væver, S. (2004): Det virker. Fangselsfunktionaren nr. 7/8, s. 6-7.

Adresse:

Justitsministeriet

Slotsholmsgade 10

DK - 1216 København K. 